\title{
Trying and Failing and Trying Again: Work in the Media
}

\author{
Rosamma Thomas*
}

\section{Abstract}

This paper is a historical auto-ethnographic account by a middle aged journalist who has worked in the English language media in India for about 20 years. English language media staff is among the best paid in the country. Even so, work conditions are far from ideal, and the pandemic this year has rendered several journalists jobless. This is a personal account of one career trajectory that spans across book publishing, national radio, newspapers and a news agency. Growth prospects are curtailed for women in news media; one boss at the Times of India, India's largest English daily, told the author that her "body language" betrayed a lack of interest in work.

Keywords: Journalism, labour, newspaper, radio, freelance, news agency

I'm writing a personal account of my experiences, working for the media in India. I've worked with the All India Radio as a presenter of music shows and as a newsreader, with publishing houses based in New Delhi, written reports for non-governmental organizations and worked as a reporter and on the desk with different newspapers, and with news agency Indo-Asian News Service (IANS). I began working in 1999, and have had spells of joblessness and freelance work in between.

My work on All India Radio was as a casual newsreader and presenter of music shows on FM radio. It was work I initially enjoyed very much, but there was no way I could make a decent

\footnotetext{
*Independent Journalist, rosammat@gmail.com
} 
living from radio - the contract was renewed every month, and there was a ceiling on the number of programmes one could do in a month; one could earn, in the 1990s, about Rs3000 each month from such work. There were days when I would go in for a late-night show and wait all night for a morning show to conclude before returning. One was paid by the hour, about Rs 500 for each hour one was on air.

All India Radio has a history that goes back to 1936, when different broadcasting units spread across the country were brought together under one umbrella organisation. "State-owned public media exists because society acknowledges that free market is not best placed to deliver certain public goods," writes Rajesh Tahil in a Scroll.in article of 2016, to mark 80 years of AIR. However, AIR has fallen far short of its mandate, and few urban listeners with a choice of other radio stations to tune in to ever listen to it anymore. In the 1990s, there were still newsreaders of some renown working for it, like Vijay Daniels, a man of wry humour. However, with almost no fresh recruitment of regular newsreaders and excessive dependence on staff that held contracts that were renewed each month, the broadcaster was being drained of the ability to function with any professionalism. In 2019, even the overnight national channel and regional training academies were shut, as "costcutting" measures.

By the time I started radio work in the 1990s, there were only about three people who were regular newsreaders, who were employees of AIR. All the others - about 30 of us - were on casual contracts renewed every month. There was no hope of attending any training sessions, because we were all people with other day jobs to pay our bills; there were also no training sessions for the regular staff, who worked with little feedback other than what was received from listeners. While there was scope for some creativity if you were presenting a music show, you were barred from even changing one word in the written script handed over to you while reading the news. It was clear that radio, with such enormous potential, could not continue for long in that vein. The high of reading the news, sitting in the newsroom and having discussions with other newsreaders who had been reading the news for decades and whose names were familiar would wear off soon, and the whole 
thing, appeared, in time, to be just a chore. News reading is not journalism, and at AIR there were bureaucrats of the Indian Information Service who wrote the script that was read out by newsreaders. Older news readers would recount how even those just typing out bulletins in the old newsrooms, engaged as clerks in the news section for years, were so adept at their work that they could spot mistakes and make corrections; that level of attention to detail, however, was absent by the time I was part of the newsroom; even these functions were by then being handed out on contract.

Even so, I remember the thrill of doing it in the early days, the hours spent studying what music would be played or the time spent reading the script before the news went on air. I think sometimes that if radio was a little more vibrant, if there were more local stations that did news and cultural programmes that local communities could contribute to, we might have a way of keeping communities together and spreading education about local issues. Indu Ramesh, who retired as director of the Bangalore station of AIR a few decades ago, explained in a conversation with this author that AIR spread information about such sensitive issues as limiting the number of children in each family. However, the power of radio is not tapped completely and the government routinely issues circulars that are quite banal. Like this one to popularize Yoga Day. https://mib.gov.in/sites/ default/ files/ Advisory\%20regarding\%20IDY.pdf

One collegemate from Karnataka in Delhi University once mentioned to me that her father, a farmer, would tend to his cows while hearing the news over radio in the morning. Since listening to radio does not require one to be rooted to one spot as watching TV does, there are whole groups of workers for whom radio is the superior medium. There are now about 180 community stations, and radio was used to convey information after natural disasters -like the 2013 floods in Uttarakhand. Private radio stations, for reasons of "national security" cannot broadcast news. And the government station has been gradually killed off, with boring content and huge staff shortage.

Radio is a medium that could be revived. The government has the wherewithal already in place; with adequate funding, 
professionalism and greater autonomy from government, interesting programmes that draw large number of people could easily be created. Its potential as a tool for education has not been fully tapped. Though, given the current situation, keeping that hope alive has become hard.

Alongside radio, for some years, I worked as a book editor with publishing houses, copy editing text, writing blurbs of books and coordinating with authors and designers before sending off material to printers. Oxford University Press in New Delhi was one of the first publishing houses I worked with, where I edited Sociology, Political Science and History texts for the academic publishing programme. I had finished an MA in Sociology from the Delhi School of Economics, and it was nice to see the texts of my former teachers as manuscripts or as printed books that needed to be reprinted. It was work I thought I might enjoy, but in the manner in which the publishing house was organized, there was a hierarchy that made any enjoyment impossible. Besides, books were churned out at such a furious pace that one could scarcely read them all. I wrote the blurbs for several books, but without reading as much of each of them as I might have liked. I had recently finished a Master's degree at university, and was disheartened that a publishing job involved so little real reading. In the early years of this century, OUP India was re-printing several old books or slapping two or three books together into new compendiums. Omnibus editions were being marketed, putting together two or three books by one author whose books had done well in the market in the past, the Jim Corbett Omnibus, for instance.

One book I had handled was by Kashmiri sociologist TN Madan. His study of the Pandits of rural Kashmir was being reissued, and a large number of photographs were received as part of the process of reprinting. I had to return these photos, and discovered after I had sent off one batch that a few more remained with me. So I sent them off in another envelope - and that did not go down very well with the punctilious Madan, who complained to my boss.

The woman at the helm of the academic publishing programme at that time, in the late 1990s, was a renowned termagant. Few people who entered her cabin emerged unscathed. I was too low in the 
hierarchy to have direct encounters with her, but a series of problems with the strict organization of the hierarchy meant that I could not have suffered a long tenure at OUP. The good thing, though, was that I did make one friend at the publishing house that I shared a flat with for many years; this friend remains even today a close friend. My stint at OUP ended abruptly after I was told my initial period of training would be extended by a few months, although the contract had mentioned a probation of only six months. I resigned, and shot off furious stinkers to all and sundry.

I sat jobless for some months, my kind flatmate bearing more than her fair share of our joint expenses. Then I found work with one half of what used to be Kali for Women, a feminist publishing house called Women Unlimited. I travelled a long distance each day to the office at Hauz Khas (New Delhi) from the flat in Patparganj, and it was a small cottage industry of an office with the domestic staff of publisher Ritu Menon also serving some functions at the office. The publisher would often be away travelling the world, and the small number of staff held fort at the publishing house. It was clear that Ms Menon needed only someone to support her work - not young people who could be nurtured over time to take over some of her functions. Besides, despite her reputation as a fierce feminist, she also had no qualms making deeply hurtful personal comments. During one discussion on HIV and AIDS, for instance, there was talk of how, in reports from Africa, girls were raped because infected men were told that sex with a virgin was a possible cure. She looked at me with an expression I will not forget, and said, "Yes, but not sex with a 29-year-old virgin." I was 29 at the time, and she likely assumed that being single, I was a virgin.

She was quite suspicious, and when she saw me at the computer browsing my email, for instance, she would assume I was just goofing off and lazing off at work. It did not help that she had few people to monitor, so I was never far from her gaze. There was just one wall between the boss's room and mine, and any phone conversation (those were days before mobile phones) or talk with a visitor could be easily monitored. After an year of work, she raised my salary by Rs1000. And every opportunity she got afterwards, she mentioned the raise. So that too was not the most pleasant workplace in the world. We squabbled and I walked off in a huff. 
In 2007, after taking several months off to take care of some family responsibilities, I moved to Bangalore and took up work with an NGO with operations in rural Tamil Nadu and Karnataka. My work involved writing material that went to sponsors of the work in the UK. I found that work on the ground did not accord with what was sent out in the reports we sent, all typed up and neat. I tried raising some issues of money being spent needlessly; the boss called me into his cabin and told me it was not working, I could leave.

So there I was out of work again. By this time, I'd begun to do some writing as a freelancer and got some work with the Bangalore edition of The Hindu, and was later offered a job with the New Indian Express in Bangalore - that was a happy time. I would work just four hours at the office, helping edit stories and getting them laid on the page. The rest of the time, I was free to travel or write. That was a dream, but dreams end. The boss I worked with moved on, and the fellow who replaced him did not understand the four-hour work I did. There were tussles and I was fortunate that a new newspaper was launched in the city at that time and offered me a job. I moved to a desk job, but that meant rather long hours of work at night.

That became my routine for the next few years, though I never quite liked it. I moved back to Delhi for a while. I worked with Indo-Asian News Service, a news agency, on the desk. This was the first time I was working with an agency, and had no prior experience a routine that never let the pressure of the deadline slip; there was a constant flow of stories to be edited, and we worked with limited staff. Since the pressure never let up, even taking a break for tea and asking a colleague to accompany you was not appreciated. It was an open office. I joined in 2011, and in just a year had begun to feel the tiredness in my bones. I worked shifts, and there were frequent changes in the shift timings. I also commuted a long way to work, and although I was still in my 30s then, I felt my feet swell, and it felt like my health was being affected by the strange work routine. There was, however, one senior woman who got a full weekend off work while all the rest of us got only one day off each week. She had regular working days without changing shifts. That was apparently written into her 
contract - so no matter how unjust, once it was inscribed in a contract, it was beyond question. After raising awkward questions on email that made people wary of me, I applied to the Times of India.

Given the chance, I jumped to the Times of India, which in 2013 launched editions that would go out to Dehradun, Meerut, Agra and Bareilly. The desk for these editions operated from New Delhi. It was to this team that I was hired, and I found myself editing vast swathes of the newspaper, and still getting bossed around by men who seemed not particularly talented as journalists. I would discover that Times of India had just one woman heading a team of journalists - all the other team leaders were men, mostly Bengali; and Brahmin. "Over 95\% of owners of the mainstream media including print and television come from dominant caste backgrounds. About $70-80 \%$ of the topmost positions are occupied by dominant caste men," said journalist Jeya Rani at a meeting of the Network of Women in Media in 2016. It may be pertinent to mention here that in the lockdown to prevent spread of the coronavirus in 2020, the four editions launched in 2013 were all clubbed into one by the Times of India.

I opted for a transfer to Jaipur, where I spent a rollicking two years, from 2016-2018, as a reporter; finding stories that I would get quite drawn into and making friendships that would lead to even more stories. However, the chief minister at the time, Vasundhara Raje, and her team of bureaucrats were not happy with many of my reports, and I was abruptly transferred to Pune, removed from reporting and placed on the desk.

I worked on the desk, where ahead of state assembly elections in 2019 I was piqued to find how stories that reporters filed would be killed, no explanations offered. I was told at appraisal time that my "body language" betrayed no desire to work; that I made no pages, so it was not enough to edit 15 copies a day. I could not care to be decorous in my expression, and told the boss he could "screw" my appraisal. And that's what he went ahead and did. I was later given a "needs improvement" appraisal, the lowest possible grade one could get. I resigned, in protest. 
It may be pertinent to mention here that while being transferred from Jaipur to Pune, I was issued transfer orders over email, with no prior warning. I accepted the transfer, found a packer and mover, hunted for a house in a new city on my own, with no help from the HR department. When I submitted my bills for reimbursement, I was told they would not be passed unless the editor in chief approved them, which he did. That a single woman could be served transfer orders without consultation, and expected to move and set up home in a new city with no support from the HR department - that didn't seem strange to anyone, and I too did not question it at the time.

I now work as a freelancer in Pune, taking up writing assignments on small fellowships or doing news reports that are modestly paid. I'm reasonably healthy at present and have no medical bills. I know that this existence is precarious, but when I consider that my previous boss at TOI Jaipur is now a cancer survivor, and that another former colleague at TOI is now under treatment for cancer, I feel we are all, working or unemployed, in a precarious state. And how can one complain these days, when the coronavirus lockdown has rendered so many workers destitute? So I try and surround myself with music and hope, and carry on.

Even as I send this piece off, there are reports of people from prominent newspapers being laid off. https:// www. newslaundry.com/ 2020/05/30/ive-been-forced-to-resign-a-tightlipped-ht-media-lays-off-over-100-employees; https:// www. newslaundry.com/2020/05/21/times-of-india-shuts-editionslayoffs-begin-amid-uncertainty; https:// www. punekarnews.in/ pune-sakal-times-newspaper-shuts-down-amid-lockdown-50journalists-others-lost-jobs /

Work seems precarious in the newspaper industry, and actually all journalism seems threatened. Investigative reporters are attempting to raise money through direct appeals to readers - Ravi Nair, who wrote the first Rafale corruption reports, Saket Gokhale, who has continued to pursue matters through Right to Information applications and Paranjoy Thakurta, senior journalist who has also written exhaustively about paid reports, have all resorted to crowdfunding. 
We do not have a viable mechanism to make journalism sustainable. While the giant mainstream press seems to have succumbed to the pressure to conform to government diktat, a vigorous few online sites - The Wire, NewsClick - continue to perform their role as watchdogs on extremely tight budgets.

In 1986, National Book Trust brought out a small children's book, "The Story of Our Newspapers" by Chanchal Sarkar. I bought a copy of it in 1997, for Rs 8.50. To conclude, I'd like to borrow the last paragraphs of Sarkar's book:

"In democratic countries everybody, including governments, has come to accept that the people have the right to know what is happening in the country. People should be able to read in the papers, see on the television screen and hear over the radio what is going on. (There was no internet yet). Government policies must be announced and talked of in public. Some countries even broadcast their Parliament sessions live. Many opinions must survive and have fair play.

This gives a special role to the mass media. Even though the electronic media, TV and radio, have spread like wildfire, newspapers have stood their ground. TV and radio, however, can and have made papers change, change very much. Newspapers have become more thoughtful, more inclined to carry views, more apt to think of special groups of readers. But neither TV nor radio can push newspapers aside. Newspapers, often very small ones, have always played a very important part in keeping a revolution going. Even under the most oppressive regimes they have circulated secretly.

Journalists, therefore, have a very special responsibility. They are expected to be people with an outsize conscience, fearless and fair."

\section{References}

'How All India Radio Lost Its Way On Its 80-Year Journey', June 22, 2016, Scroll.in https://scroll.in/article/810142/how-all-india-radio-lostits-way-on-its-80-year-journey

'Prasar Bharti to shut down All India Radio's national channel, five regional academies' The Print website, January 4, 2019 
https:/ / theprint.in/india/governance/prasar-bharati-to-shut-downall-india-radios-national-channel-five-regional-academies/173219/

Is radio relevant in the 21st century? $\mathrm{N}$ Ramakrishnan, The Hindu, January 11, 2018. https://www.thehindu.com/opinion/op-ed/is-radiorelevant-in-the-21st-century/article22423373.ece

'Why can't pvt radio broadcast news: Supreme Court to Centre' Times of India November 14, 2017

'The Dalit Voice is Simply Not Heard in the Mainstream Media' The Wire, November 15, 2016. https://thewire.in/media/caste-biasmainstream-media

Here is a link to one report that was not appreciated by the Times of India: https://thewire.in/media/times-of-india-vasundhara-raje-bjpnarendra-modi-press-censorship

https://paranjoy.in/crowdfundingParanjoyGuhaThakurta's crow dfunding call https:// www.nytimes.com/ 2020/04/02/ world/ asia/modi-india-press-media.html Press freedom in India; article in the New York Times

The Story of our newspapers Chanchal Sarkar, National Book Trust First Edition 1986; third reprint 1997 